\title{
Microplastic in Commercial Fish in the Mediterranean Sea, the Red Sea and the Arabian Gulf. Part 1: The Mediterranean Sea
}

\author{
Rana Zeeshan Habib1, Thies Thiemann ${ }^{2 *}$ \\ ${ }^{1}$ Department of Biology, College of Science, United Arab Emirates University, Al Ain, Abu Dhabi, UAE \\ ${ }^{2}$ Department of Chemistry, College of Science, United Arab Emirates University, Al Ain, Abu Dhabi, UAE \\ Email: ^thies@uaeu.ac.ae
}

How to cite this paper: Habib, R.Z. and Thiemann, T. (2021) Microplastic in Commercial Fish in the Mediterranean Sea, the Red Sea and the Arabian Gulf. Part 1: The Mediterranean Sea. Journal of Water Resource and Protection, 13, 563-587. https://doi.org/10.4236/jwarp.2021.138031

Received: June 26, 2021

Accepted: July 27, 2021

Published: July 30, 2021

Copyright $\odot 2021$ by author(s) and Scientific Research Publishing Inc. This work is licensed under the Creative Commons Attribution International License (CC BY 4.0).

http://creativecommons.org/licenses/by/4.0/

\begin{abstract}
Microplastic has become a ubiquitous environmental pollutant. Microplastic in the oceans has detrimental effects on aquatic organisms. The presence of microplastic in marine fish heightens the chance of finding microplastic in seafood targeted for human consumption. The Mediterranean Sea is known to suffer from significant plastic pollution. It is also one of the most thoroughly studied water bodies in regard to microplastic contamination. The manuscript reviews the available literature of 2015-2021 on the presence of microplastic in commercially important fish species in the Mediterranean Sea. The literature data on microplastic content on beaches, in subtidal sediment, in the sediment from the ocean floor and in surface water of different regions of the Mediterranean Sea is reviewed, also.
\end{abstract}

\section{Keywords}

Review, Commercial Fish, Mediterranean Sea, Microplastic, Environmental Pollution

\section{Introduction}

Microplastics (MP) are small plastic particles of $5 \mathrm{~mm}$ or less in size. Either, these particles are synthesized in this small size (primary microplastics) or stem from the fragmentation of larger plastic pieces (secondary microplastics). One of the final resting places of MP is aquatic ecosystems, where there is significant transport of MP from land to water through run-offs [1], via wastewater treatment plants [2] and through air movement and subsequent atmospheric deposits [3] [4]. In addition, there is significant direct plastic input into the sea 
through fishing operations and through shipping. Almost all ocean regions are affected by MP, where MP has been found in Arctic [5] and Antarctic waters [6] as well. The Mediterranean Sea, the Arabian Gulf and the Red Sea are the most important larger water bodies for the MENA region. Not only do they provide the countries along their shores access to trading routes, but they are still home to some of the richest fishing grounds in the world. All of them are semi-enclosed, enjoy heavy ship traffic, and are situated in a relatively arid region, with the Red Sea being the northernmost tropical sea. While the fish caught in the Mediterranean Sea decreased a little over the last 10 years, it was a little over 800.000 tons per year in 2018, with herring, anchovies and sardines contributing $49.5 \%$ of the total [7]. Fish catches in the Arabian Gulf have averaged 331,827 tons annually (2004-2012), with a minimum of 208,520 tons in 2004, and a maximum of 421,606 tons in 2012 [8] [9]. The total fish captures in the Red Sea amounted to 60,900 tons in 1986 [10]. With the total fish captures from the Red Sea of the Kingdom of Saudi Arabia reaching 22,700 tons in 1986 [10] and 24,016 metric tons in 2018 [11], there is a slight increase. There has always been a worry in regard to contamination in fish being passed on to humans who consume it, be it heavy metal contamination [12] [13] or persistent organic pollutants. The latest in line is MP. MP has been found in fish sold in fish markets around the world [14] [15], and thus the level of ingestion and uptake of MP by fish as well as the abundance of MP in aquatic ecosystems is of importance. There have been reviews both on MP in the Mediterranean Sea [16] [17] [18], on the effect of marine litter on fish [19] [20] [21] as well as on MP in the Arabian Gulf [22]. Less has been reported from the Red Sea and there is currently no review on MP in the Red Sea. The current contribution, the first of two, reviews the occurrence of MP in commercially valuable fish species in the Mediterranean Sea. 22 countries from three continents, home to around 480 million people, surround this semienclosed sea, where $33 \%$ of the population lives along with the coastal areas and roughly $55 \%$ of the population resides in coastal hydrological basins [23], where population increase has gone hand in hand with increasing environmental pressures. The Mediterranean Sea, which is known as a hotspot of plastic contamination, is likely the most studied water body in regard to microplastic contamination, with university research groups, non-governmental, governmental and interregional organizations such as UNEP and EEA providing new citable data on a weekly basis. In the following, the authors have collated the available research data on MP contamination in commercially important fish species of the Mediterranean of the last decade.

\section{Data Collection}

To undertake this review, the authors have used the databases Scopus ${ }^{\oplus}$, Scifind$\mathrm{er}^{\circledast}$ and Web of Science ${ }^{\oplus}$. Typical keyword combinations used were "Mediterranean AND microplastic", "Mediterranean AND microplastic AND fish", "Mediterranean AND beach AND microplastic", Mediterranean AND sediment AND microplastic" to give as an example 299 entries, 99 entries, 31 entries, and 89 en- 
tries, respectively, in Web of Science ${ }^{\circledast}$. Publications by governmental organizations, intergovernmental organizations (IGO's) and or nongovernmental organizations (NGO's), which are often not abstracted by the above databases, were searched for on the world-wide-web, utilizing the search words above. Abstracts of all entries were screened. When the abstract indicated that a quantitative analysis of microplastic in the region of the Mediterranean Sea was presented, the paper was obtained through the UAEU university library. All pertinent references in the given papers were screened for any missed publications. The "forward" citations given in the databases for the entries found in the databases were also screened for any missed publications. Papers were included in this review that detail quantitative analyses of microplastic in fish, water, beaches/coasts and sediments within the region of the Mediterranean Sea. No review was discarded on the basis of the actual data presented. Where data seemed to be in conflict with other published data, the conflict was stated in the review without evaluation of the actual data. At a late stage of preparing the manuscript, publications on microplastic in fish that are not deemed of commercial value such as the lanternfishes (Myctophiformes) were excluded from the review. To decide upon the commercial values of different fishes, capture production statistics from FAO Fisheries \& Aquaculture were used.

\section{Microplastic-Composition, Additives and Adsorbents and Their Potential Effects on Marine Organisms}

MP can come in different forms such as pellets, fragments, filaments/fibers and films, and be made of a number of different polymer types such as polyethylene $(\mathrm{PE})$, polypropylene (PP), polyurethane (PU) and polystyrene (PS). Interestingly, from a meta-analysis of 39 studies from different regions, Erni-Cassola et al. [24] determined the make-up of the most abundant polymers discharged into water bodies to be the following: PE (polyethylene, 23\%), PP (polypropylene, $13 \%$ ), PS (polystyrene, 4\%) and PP\&A (group of polymer types formed by polyesters, PEST; polyamide, PA; and acrylics, 13\%). This coincides with the report of de Haan et al. that PE, PP, PS, polyesters are the most dominant polymer types found in the Mediterranean Sea [25]. Polymers carry additives. These can be small organic molecules such as phthalates [26], terephthalates, alkanedioates, trimellitates, trialkyl phosphates and siloxanes [27]. Furthermore, there can inorganic filling materials involved, mostly salts, that provide bulk but influence other properties of plastics as well such as stickiness of the surface of the plastic. In addition, there are colorants that can either be organic dyes or inorganic pigments. Small organic molecules can easily attach to the hydrophobic surface of the MPs, and so MPs can act as carriers of organic contaminants already present in the water body. Many of the organic compounds are known to bio-accumulate along the food chain. Thus, Capriotti et al. detected organic pollutants such as polychlorinated biphenyls (PCBs), organophosphous compounds, and polycyclic aromatic hydrocarbons (PAHs) on the surface of MPs collected in Italian coastal waters of the central Adriatic Sea [28]. K. Karkanorachaki et al. (2018) could 
detect concentrations of 13 different types of PAHs on the surfaces of MPs collected from 9 beaches in Crete [29]. While not necessarily having MPs as their origin, significant concentrations of the phthalates dibutyl phthalate (DBP, 0.017 - $\left.0.055 \mathrm{mg} \cdot \mathrm{L}^{-1}\right)$, diisobutyl phthalate (DiBP, $\left.0.075-0.219 \mathrm{mg} \cdot \mathrm{L}^{-1}\right)$, and $\operatorname{di}(2-$ ethylhexyl)phthalate (DEHP, $0.071-4.594 \mathrm{mg} \cdot \mathrm{L}^{-1}$ ) were found along the coast of the Mahdia governorate, Tunisia, and these phthalates were noted to bioconcentrate in the gilt-head bream (Sparus aurata) caught in the same area [DBP, 0.389 - $0.817 \mathrm{mg} \cdot \mathrm{L}^{-1}$; DiBP, 0.101 - $0.921 \mathrm{mg} \cdot \mathrm{L}^{-1}$; DEHP 0.726 - $1.771 \mathrm{mg} \cdot \mathrm{L}^{-1}$ ] [30]. M. Fossi et al. have estimated that within the Pelagos sanctuary (Ligurian Sea) the Mediterranean basking shark (Cetorhinus maximus) can ingest as many as 540 $M P \cdot h^{-1}$ based on the MP concentration data of 2012. The group links the occurrence of mono(2-ethylhexyl)phthalate (MEHP) as primary metabolite of DEHP in Cetorhinus maximus with its ingestion of MP [31]. Nevertheless, Schmidt et al. noted that in their study on the concentration of phthalates and MPs in surface seawater, sediment and zooplankton samples in Marseille Bay (NW Mediterranean Sea) no clear correlation could be seen between the two [32]. Some of the additives in microplastics are mild estrogens and could act as hormonal disruptors under certain conditions. Other possible adsorbents such as polychlorinated biphenyls (PCBs) can act as neurotoxins [33] or can exhibit genotoxicity [34]. Neurotoxicity and genotoxicity have also been documented in animals exposed to microplastics under laboratory controlled conditions along with oxidative stress, reduced food consumption, growth, reproduction and survival rates [35] [36] [37]. Metals have also been seen to hitchhike rides on plastic surfaces of MP, with a recent study from the Mediterranean Sea showing aluminum, iron, chromium, zinc, nickel, molybdenum, manganese, lead cobalt, and copper at concentrations of $\mathrm{mg} / \mathrm{kg}$ plastic and arsenic, vanadium, rubidium, and cadmium at concentrations of $\mu \mathrm{g} / \mathrm{kg}$ plastic [38].

\section{Abundance of Microplastic in the Mediterranean Sea}

The concentration of microplastic [39] as of plastic [40] in the Mediterranean Sea has been described to be very high compared to other large water bodies, representing as much as $5 \%-10 \%$ of global MP by weight [41]. Floating plastic debris in the Mediterranean Sea has already been investigated scientifically in 1980 [42]. Different models have been forwarded that reflect the input and distribution of MP in the Mediterranean Sea [43] [44]. For their model, Kandoorp et al. [43] estimated that in 2015, there was an input of 2100 - 3400 tonnes of $\mathrm{MP}$, and that of plastics released since 2006, about 170 - 420 tonnes remain afloat in the surface waters, $49 \%-63 \%$ ended up on coastlines, and $37 \%-51 \%$ have sunk down to the sea floor. With many MP possessing positive buoyancy in salt water and with microbial colonization and biofilm formation on MP changing their density over time [45], this leaves about $1 \%$ of total MP in the water column according to the model [44].

Physical studies on the occurrence of MPs along the coast, the water column, the sea floor and in marine organisms of the Mediterranean Sea are quite exten- 
sive. Thus, MP quantification in sediments along the coastline of the Mediterranean Sea has been carried out in a number of locations (Figure 1). Starting with the Northwestern coastline and then turning clockwise, the following are some of the values that have been published, given either as number of MP per $\mathrm{kg}$ of dry sediment or number of MP per $\mathrm{m}^{2}$ surface with a defined thickness of layer analyzed: Coast of Granada: Herradura (beach) (45.0 $\pm 24.7 \mathrm{MP} / \mathrm{kg}$ ), Motril (beach) $(31.5 \pm 21.5 \mathrm{MP} / \mathrm{kg})$, La Rábita (beach) $(22.0 \pm 23.2 \mathrm{MP} / \mathrm{kg})$, all Spain [46]; Denia (beach), Costa Blanca, Spain (156 $\pm 29 \mathrm{MP} / \mathrm{kg}$, [47]); Barcelona (beach), Spain (148 $\pm 23 \mathrm{MP} / \mathrm{kg}$, [47]); Andratx, Mallorca (shallow coastal sediment, $10 \mathrm{~m}$ depth), Spain (120 $\pm 100-160 \pm 90 \mathrm{MP} / \mathrm{kg}$, [48]), Santa Maria, Cabrera (shallow coastal sediment, $10 \mathrm{~m}$ depth), Spain (240 $\pm 30-900 \pm 100$ $\mathrm{MP} / \mathrm{kg}$, [48]); Es Port, Cabrera (shallow coastal sediment, $10 \mathrm{~m}$ depth), Spain (100 $\pm 60 \mathrm{MP} / \mathrm{kg}$, [48]), La Crouste, Canet-en-Roussillion (beach), France (166 $\pm 205 \mathrm{MP} / \mathrm{kg}$, [49]); Plage del Forat (beach), Paulilles, France (58 $\pm 31 \mathrm{MP} / \mathrm{kg}$, [49]), Cassis (beach), France (124 $\pm 36 \mathrm{MP} / \mathrm{kg}$; [47]); Tuscany: San Rossore (beach) (958.7 $\pm 792.0 \mathrm{MP} / \mathrm{kg})$, Marina di Vecchiano (beach) $471.3 \pm 333.0$ $\mathrm{MP} / \mathrm{kg})$, Viareggio (beach) (175.4 $\pm 42.0 \mathrm{MP} / \mathrm{kg})$, Italy [50]; Tuscany: Talamone, (sediment sample, $62 \pm 24 \mathrm{MP} / \mathrm{kg}$ ); Osa (sediment and beach, $286 \pm 37 \mathrm{MP} / \mathrm{kg}$ ) and Albegna (sediment and beach, $453 \pm 424 \mathrm{MP} / \mathrm{kg}$ ); Capalbio (beach and intertidal, $466 \pm 297 \mathrm{MP} / \mathrm{kg}$ ), Italy [51]; Tuscany: Albegna (river mouth, 57 - 395 MP/kg), Giannella (beach, 134 - 1069 MP/kg), Ombrone (river mouth, 99 - 118 $\mathrm{MP} / \mathrm{kg}$ ), Trapolla, Maremma (beach, 250 - $271 \mathrm{MP} / \mathrm{kg}$ ), Marina di Alberese (beach, $200-282 \mathrm{MP} / \mathrm{kg}$ ) [52]; Latium (shallow coastal water sediment, $3 \times 3$ sampling sites) Mignone $(485.9 \pm 133.8 \mathrm{MP} / \mathrm{kg}[10 \mathrm{~m}$ depth], $330.7 \pm 182.1$ $\mathrm{MP} / \mathrm{kg}$ [27.7 m depth], $175.4 \pm 157.9 \mathrm{MP} / \mathrm{kg}$ [35.7 m depth]; Civitavecchio 131.1 $\pm 50.7 \mathrm{MP} / \mathrm{kg}$ [10 m depth], $401.4 \pm 204.2 \mathrm{MP} / \mathrm{kg}$ [30 m depth], $339 \pm 169.5$ MP/kg [37.7 m depth]; Capo Linaro $279.9 \pm 15.5 \mathrm{MP} / \mathrm{kg}$ [10 m depth], $194.9 \pm$ 127.1 MP/kg [28.0 m depth], $116.7 \pm 34 \mathrm{MP} / \mathrm{kg}$ [37.5 m depth], Italy [53]; Sicily

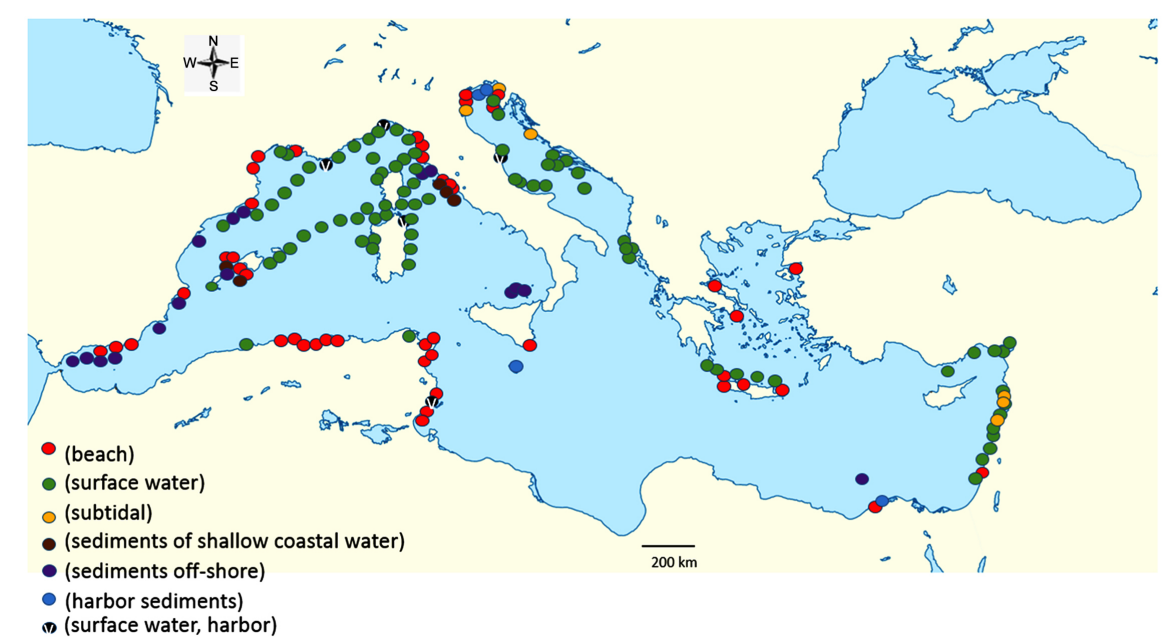

Figure 1. Sampling sites of microplastics on beaches, in coastal sediments and in surface water. 
(beach), Italy (160 $\pm 31 \mathrm{MP} / \mathrm{kg}$; [47]); La Valetta (harbor, at $4-22 \mathrm{~m}$ depth), Malta 0 - $23 \mathrm{ML} / \mathrm{kg}$ [54]; San Mauro a Mare (beach), Italy (84 $\pm 12 \mathrm{MP} / \mathrm{kg}$; [47]); Lagoon of Venice (subtidal), Italy (672 - $2175 \mathrm{MP} / \mathrm{kg}$; [55]), Caorle (intertidal area), Italy (710 MP/kg [56]); Lido de Dante (beach), Italy (1512 \pm 187 MP/kg; [47]); Gulf of Trieste, Italy (subtidal) 30 - $870 \mathrm{ML} / \mathrm{kg}$ [57]; Slovenia average of 6 beaches: Debeli Rtič, Jadranska, Simonov Zaliv, Bele Skale, Portorož, and Seča; 177.8 MP/kg (beach); 170.4 MP/kg (infralittoral [58]); Slovenia (average of 9 sampling sites: Portorož, Bele Skale, Simonov Zaliv, Izola, Koper, Ankaran, Debeli Rtič, Jadranska and Seča; $0.5 \pm 0.5$ - $1.0 \pm 0.8 \mathrm{MP} / \mathrm{kg}$; [59]); Croatia (subtidal) Pilion (beach), Greece (242 $\pm 93 \mathrm{MP} / \mathrm{kg}$; [47]); Crete (4 beach sites for quantitative analysis: Falassarna, Stavros, Petres, Analoukas: $11.2 \pm 20.8-169.8$ \pm 185.4 micropellets $/ \mathrm{m}^{2}$ and $22.8 \pm 33.6$ - $124.9 \pm 120.3$ microparticle fragments $/ \mathrm{m}^{2}$ [29]) Dikili (beach), Turkey (248 $\pm 47 \mathrm{MP} / \mathrm{kg}$; [47]); Levantine coast: Tripoli, Lebanon (4680 MP/kg), average over all sampling sites: $2433 \pm$ $2000 \mathrm{MP} / \mathrm{kg}$ [60]; Tel Aviv (beach), Israel (168 $\pm 16 \mathrm{MP} / \mathrm{kg}$; [47]); Eastern Harbor (beach), Alexandria, Egypt (242 MP/kg [61]); Coast of Tunisia (beach, 8 sampling sites: Gulf Gabes (4 sites; $139 \pm 12.2-435 \pm 34 \mathrm{MP} / \mathrm{kg}$ ), Gulf of Hammamat ( 2 sites, $145 \pm 13-606 \pm 37.5 \mathrm{MP} / \mathrm{kg}$ ), Gulf of Tunis (2 sites, $129 \pm$ 10 - $379 \pm 33 \mathrm{MP} / \mathrm{kg}$ [62]); Sidi Mansour harbor (harbor bottom), Sfax, Tunisia (252 - $5332 \mathrm{MP} / \mathrm{m}^{2}$ from $5-10 \mathrm{~cm}$ top sediment [63]); Northern coast of Tunisia (average of 5 sampling sites: Menzel Bourguiba, North Lake of Tunis, South Lake of Tunis, Goulette, Carthage; $141 \pm 26-461 \pm 30 \mathrm{MP} / \mathrm{kg}$ [64]); Bizerte lagoon, Tunisia (3000 - 18,000 MP/kg [65]); Coast of Algeria (4 sampling sites, beaches: Chapuis Beach, Joannonville Beach, Sidi Salem Beach, Cap Rosa Beach; $182.66 \pm 27.32-649.33 \pm 184.02 \mathrm{MP} / \mathrm{kg}$ [66]); West coast of Algeria (9 sampling sites, beaches: Sidi Mansour, Sablettes, Sakhra, Benabdelmalek R., Hadjadj, Petit Port (W), Petit Port (E), Sidi Abdelkader, Bahara; $7.60 \pm 18.80-66.40 \pm$ 44.95 plastic items $/ \mathrm{m}^{2}$ [67]). Clear differences in MP concentrations have been found on beaches that are cleaned regularly as compared to those that are cleaned less regularly. A distinction can be made between rural, semi-rural and urban beaches and coastlines. Some of the beaches on the Italian East coast in the regions Emilia Romagna and Veneto are MP hotspots with $>1000 \mathrm{MP} / \mathrm{kg}$ soil as are some of the sampled locations in Lebanon and Israel [60] [68]. Nevertheless, most of the analyses of Mediterranean beaches have found MP contents > $150 \mathrm{MP} / \mathrm{kg}$ soil.

Measurements on MP concentrations on sea floors in the Mediterranean Sea, off-shore (Figure 1), were reported as follows, starting with the Northwestern coastline and then turning clockwise: Spanish Mediterranean continental shelf: 10 locations at 43 - $154 \mathrm{~m}$ depth; $45.9 \pm 23.9 \mathrm{MPs} / \mathrm{kg}$ (Palma de Mallorca) - 280.3 \pm 164.9 MPs/kg (Malaga), Spain [69]; Piombino channel $31 \mathrm{~km}$-long transect from the port of Piombino (Tuscany) to the port of Portoferraio (Elba Island), at a depth of up to $71.5 \mathrm{~m}$, Italy) $0.43-4.0 \mathrm{P} / \mathrm{kg}\left(65-600 \mathrm{P} / \mathrm{m}^{2}\right)$ [70]; Central Adriatic Sea $(140 \mathrm{~km}$ long East-West transect from Pescara to the island of Pianosa at depths of $7 \mathrm{~m}$ to $142 \mathrm{~m}$ ): $0 \mathrm{MP} / \mathrm{m}^{2}-75 \pm 15 \mathrm{MP} / \mathrm{m}^{2}$ [71]; Aeolian 
archipelago: Alicudi $(347.9 \pm 87.4 \mathrm{MP} / \mathrm{kg})$, Filicudi $(186.2 \pm 161.1 \mathrm{MP} / \mathrm{kg})$, Vulcano $(534.8 \pm 24.3 \mathrm{MP} / \mathrm{kg})$, Lipari $(678.7 \pm 345.8 \mathrm{MP} / \mathrm{kg})$, Panarea $(484.2 \pm$ $124.4 \mathrm{MP} / \mathrm{kg})$, Stromboli $(151.0 \pm 34.0 \mathrm{MP} / \mathrm{kg})$, and Salina $(219.1 \pm 198.7$ $\mathrm{MP} / \mathrm{kg}$ ), all at a depth of $30 \mathrm{~m}$ [72]; Middle Adriatic Sea: Božava (at $45 \mathrm{~m}$ depth, $190 \mathrm{ML} / \mathrm{kg}$ ), Vir (at $78 \mathrm{~m}$ depth, $780 \mathrm{ML} / \mathrm{kg}$ ), Croatia [73]; Telaščica bay (Eastern Adriatic Sea): 10 locations, at $3-15 \mathrm{~m}$ depth, $3.4-84 \mathrm{MP} \cdot \mathrm{kg}^{-1}$ [74]; Nile Deep Sea Fan: (at $1176 \mathrm{~m}$ depth, $0-1 \mathrm{MP} / 25 \mathrm{~cm}^{2}$ [75]).

Measurements on the MP concentration in the water at different locations within the Mediterranean Sea have been published, also (Figure 1). The following gives some of the published values, starting with the Northwestern coastline and then again turning clockwise: West Mediterranean Sea: Balearic Islands, transect Balearic islands-Sardinia/Corsica, Sardinia, Corsica, 41 sampling sites (0.0057- $\left.0.13 \mathrm{MP} / \mathrm{m}^{2}\right)$ [76]; Balearic Islands (average over 20 sampling sites) $\left(0.875 \mathrm{MP} / \mathrm{m}^{2}\right)$, Spain [77], Gulf of Lion: Rhone river plume (0.059 - 0.40 $\left.\mathrm{MP} / \mathrm{m}^{3}\right)$, Bay of Marseille $\left(0.317-1.16 \mathrm{MP} / \mathrm{m}^{3}\right)$ [78], North Western Mediterranean Sea: Gulf of Lion-Marseille-Toulon-Portofino-Elba-Ligurian Sea-sea off west coast of Corsica (average $0.116 \mathrm{MP} / \mathrm{m}^{2}$ ) [79]; Toulon (harbor), France $\left(0.006-0.041 \mathrm{MP} / \mathrm{m}^{2}\right)$ [80]; French Riviera-Ligurian Sea: Toulon-Ste. Maxime-Cannes-Nice-Ventimiglia-Savona-Genoa-Dyfamed sampling site-Calvi $\left(0.021-0.578 \mathrm{MP} / \mathrm{m}^{2}\right)$ [81]; Genoa (harbor), Italy $\left(0.0056-0.380 \mathrm{MP} / \mathrm{m}^{2}\right)$ [79]; Olbia (harbor), Italy $\left(0.0017-0.0058 \mathrm{MP} / \mathrm{m}^{2}\right)$ [80]; Ligurian-Thyrrenian Sea: $0.19 \mathrm{MP} / \mathrm{m}^{2}$ (average over 34 sampling sites, data from 2018) [82]; Ligurian-Thyrrenian Sea: 20 sampling sites (data from 2019) $\left(0.0013-3.81 \mathrm{MP} / \mathrm{m}^{2}\right)$ [83] Tuscany: 4 transects off-coast (at $0.5-5-10-20 \mathrm{~km}$ ) (average: $0.26 \pm 0.33$ $\mathrm{MP} / \mathrm{m}^{2}$ ) [84]; Bay of Calvi, $\left(0.062 \mathrm{MP} / \mathrm{m}^{2}\right)$, Corsica, France [85]; Northwest coast Sardinia: Asinara National Park, off-shore $\left(0.17 \pm 0.32 \mathrm{MP} / \mathrm{m}^{3}\right)$ [86]; West coast of Sardinia: off-shore $\left(0.15 \mathrm{MP} / \mathrm{m}^{3}\right)$; Mal di Ventre $\left(0.10 \pm 0.04 \mathrm{MP} / \mathrm{m}^{3}\right)$; Caletta $\left(0.01 \pm 0.00 \mathrm{MP} / \mathrm{m}^{3}\right)$; Marceddì $\left(0.18 \pm 0.03 \mathrm{MP} / \mathrm{m}^{3}\right)$; Tirso $(0.14 \pm 0.08$ $\left.\mathrm{MP} / \mathrm{m}^{3}\right)$ [87]; Marche: San Benedetto del Tronte (harbor) $\left(0.76 \pm 0.48 \mathrm{MP} / \mathrm{m}^{3}\right)$, San Benedetto del Tronte $(0.93 \mathrm{~km}, 2.78 \mathrm{~km}, 11.1 \mathrm{~km}$ off-shore) $(0.17 \pm 0.11$ $\left.\mathrm{MP} / \mathrm{m}^{3}-62.0 \pm 8.03 \mathrm{MP} / \mathrm{m}^{3}\right)$, Grottammare $(0.93 \mathrm{~km}, 2.78 \mathrm{~km}, 11.1 \mathrm{~km}$ off-shore) $\left(0.17 \pm 0.02 \mathrm{MP} / \mathrm{m}^{3}-3.01 \pm 1.82 \mathrm{MP} / \mathrm{m}^{3}\right)$, Italy [28]; Bay of Trieste, Slovenia: 17 samplings $\left(0.19-41.3 \mathrm{MP} / \mathrm{m}^{3}\right)$ [88]; Middle Adriatic Sea: Zadar channel $\left(0.1 \mathrm{ML} / \mathrm{m}^{3}\right)$, Jabuka pit $\left(9.7\right.$ particles $\left./ \mathrm{m}^{3}\right)$, Croatia [73]; Adriatic Sea: (Bay of Trieste, Gulf of Split, Corfu) (average: $0.315 \pm 0.569 \mathrm{MP} / \mathrm{m}^{2}$ ) [89]; Crete: 25 sampling sites $\left(0.119 \mathrm{MP} / \mathrm{m}^{2} ; 0-1160 \mu \mathrm{g} / \mathrm{m}^{2}\right.$ [90]); Iskenderun Bay, Turkey (0.225 MP/m $\mathrm{m}^{2}$ [91]); (1.067 MP/m $\mathrm{m}^{2}$ [92]); Mersin Bay, Turkey (0.683 MP/m² [91]), Turkish coastline: Mersin-Adana-Hatay $\left(0.032-0.52 \mathrm{MP} / \mathrm{m}^{2}\right)$ [93]; Levantine coastline: Sidon $\left(6.7 \mathrm{MP} / \mathrm{m}^{3}\right)$, Beirut $\left(2.35 \mathrm{MP} / \mathrm{m}^{3}\right)$ average over all sampling sites, Lebanon: $4.3 \pm 2.2 \mathrm{MP} / \mathrm{m}^{3}$ [60]; Israeli coastline: 18 sampling sites-Akko $\left(2.09 \pm 1.97 \mathrm{MP} / \mathrm{m}^{3}\right)$, Herzlyya $\left(2.53 \pm 2.41-3.05 \pm 2.14 \mathrm{MP} / \mathrm{m}^{3}\right)$, Jaffa $\left(4.71 \pm 3.26 \mathrm{MP} / \mathrm{m}^{3}\right)$, Ashdod $\left(6.72 \pm 8.48 \mathrm{MP} / \mathrm{m}^{3}\right)$, Askelon $(5.11 \pm 8.76$ $\mathrm{MP} / \mathrm{m}^{3}$ ) [68]; Bizerte lagoon, Tunisia (453.0 $\pm 335.2 \mathrm{MP} / \mathrm{m}^{3}$ [94]); Bou-Ismail Bay, Algerian coast: $\left(0.86 \pm 0.35 \mathrm{MP} / \mathrm{m}^{3}\right.$; [95]). 
While litter concentration is generally high on the seafloor along the Mediterranean coast in comparison with many other European coastlines, the concentration is particularly high near shipping lanes, mussel farms, the entry of large rivers [78] [96] and near large cities [97], for instance along the south-east French Mediterranean coast [98], where the litter count was up to $913 \pm 80$ items $/ \mathrm{km}^{2}$, with $80 \%$ of the items being plastic [97]. Constant et al. [4] have calculated the annual MP loads of the rivers Rhône and the much smaller Têt to be 5.92 and $0.09 \mathrm{t}$, respectively, that are discharged into the Mediterranean. Apart, from the Rhone, large discharges can also be seen from the Po, Seyhan and Nile rivers [99]. In this respect, hydrological data of such river basins such as the Seyhan river will be of value to predict future discharges [100]. Large cities that seem to contribute significantly to plastic input are Izmir, Barcelona, Alexandria and Tel Aviv, in the vicinities of which MP concentrations are especially high [99]. Vlachogianni et al. (2017) [101] found that shoreline and recreational activities accounted for approx. $33.4 \%-38.5 \%$ of the marine litter, in general, in different marine compartments in the Adriatic and Ionian Sea, with up to $23.5 \%$ coming directly from the sea, and with $6 \%$ (beach), $9 \%$ (surface water) and $17 \%$ (seafloor) coming from fishing gear. MP concentrations are often higher near the coast, i.e., within $1 \mathrm{~km}$ of the coastline than further out, though patches with high concentrations of MP can also be found at great distances from the coast (eg., $>50 \mathrm{~km}$ ) [81]. Further off-shore, ocean currents appear to transport microplastics from shallow to deep water, dispersing MPs from open slopes and entraining microplastics transported downslope by gravity currents in submarine channels linked to the coast [102] [103]. Thermohaline bottom currents influence the distribution of MP on the seafloor, leading to hotspots of up to 3.8 MP/g floor sediment [102]. Kane et al. [102] found lower MP concentrations on the continental shelf and the upper slopes than at a water depth range of 600 to $900 \mathrm{~m}$, near the sea bottom. Thus far, research has not shown that the nature/character of the sea floor, apart from its contours, and the marine habitat it represents plays a significant role on MP accumulation [56]. As the distribution of MP is driven in part by seasonally changing currents and as plastic input varies throughout the year as well, local MP concentrations can have considerable seasonal variations [95]. Nevertheless, by region, certain areas such as the Ligurian Sea (mean value $0.94 \mathrm{MP} / \mathrm{m}^{3}$ ) were found to have a higher MP concentration than others such as the Sardinian Sea (mean value $0.13 \mathrm{MP} / \mathrm{m}^{3}$ ) [31].

\section{Microplastic Abundance in Fish Species in the Mediterranean Sea}

The authors have found reports for 87 fish species for which plastic ingestion has been recorded, many of which are commercially important. The most affected are demersal (30.4\%), pelagic (15.9\%), benthopelagic (24.6\%), bathypelagic (11.6\%), and bathydemersal (5.8\%) fish [18]. Especially the demersal species are of economic importance. The demersal/semi-pelagic bouge fish (Boops boops) has been subject to a number of studies on microplastic ingestion [104] [105] 
[106] [107] [108]. The global annual catch of B. boops is estimated to be 40.850 tons (as of 2016 [109]). Mediterranean fisheries rely on this fish. In Algeria, it is ranked 4th in commercial importance after sardine, mackerel and round sardinella, representing 3\% of the catch [110]. In all studies except for one (South Sardinia [107]), B. boops shows a high ingestion of MP, especially along the Spanish, French and Italian coasts. Ingestion varies significantly from site to site. Garcia-Garin et al. see B. boops as a bioindicator of MP pollution along the Spanish Catalan coast, finding more fish with MP ingestion caught in the area off Barcelona (65\%) than in the areas off Blanes and Cap de Creus $35 \%$ and $38 \%$, respectively) [104]. Nadal et al. [105] showed that within the Balearic Islands, a big difference was noted in MP ingestion by B. boops when comparing Eivissa (78.13\%) and Mallorca (39.55\%). Even within Mallorca, very different MP ingestion values for B. boops were found for e.g. Cala Ratjada (51\%) and Cap Blanc (24.68\%). The European pilchard (sardine) (Sardina pilchardus) is another fish that is of tremendous commercial importance for the Mediterranean, making for about $20 \%$ of the fish landings in the Mediterranean Sea (59\% of the landings in Algeria [110]). Numerous studies on the fish [93] [101] [108] [111] [112] [113] [114] have shown that its MP ingestion is high in most regions of the Mediterranean, where often over $12 \%$ of the fish have been found with MP in their gastrointestinal tract with the highest frequency of $96 \%$ reported in the Adriatic Sea [115]. Interestingly, less is known about the MP ingestion behavior of the round sardinella ( $S$. aurita), a species that is fished on both sides of the Atlantic as well as in the Mediterranean (22\% of the landings in Algeria [109]). Studies are known from the West African coast [116], where $22 \%$ of $\mathcal{S}$. aurita showed MP ingestion, but the authors could only find a single study from the Mediterranean which comes from an extreme MP hotspot (Eastern Harbor, Alexandria, Egypt; [117]) and describes a situation where all fish showed MP ingestion at a very high level. The European anchovy (Engraulis encrasicolus) is a major commercial fish, mainly caught in the Mediterranean Sea and the Black Sea, the 508,959 tonnes caught in 1995 making up 82.2\% of the world production. MP ingestion in Engraulis encrasicolus has been studied both in the Western Mediterranean Sea and the Eastern Mediterranean Sea (Levantine coast, [60]). MP ingestion for this fish in the Western Mediterranean Sea has been found to be moderate ( $0 \%-14.3 \%$ [60] [108] [110] [118]). Frequently studied are the red mullet (Mullus barbatus) and the striped red mullet (Mullus surmuletus). Both are seen as delicacies in the Mediterranean since the era of Ancient Rome. Alone in the Strait of Sicily, 1700 tons of red mullet are landed annually (data of 2015 [119]). Usually, the fish feed over soft substrates such as sand. All except for one study have found MP ingestion in red mullets to some degree, where especially in the Ionian Sea and along the coast of Turkey high ingestion rates were found, with $32 \%$ [113] [114] and 42\% [93], respectively, of the fish exhibiting MP in their gastrointestinal tract. Avio et al. reported high ingestion rates from the Adriatic Sea as well, with $64 \%$ of the fish specimen with MP. Also, red striped mullets caught in Adriatic Sea [113], along the coast of Turkey [93] 
and also in the Balearic Islands [120] were found frequently with MP content (23.5\% - $70 \%$ of the fish). Other goatfish species that have been studied include the golden grey mullet (Chelon auratus), the goldband mullet (Upuneus moluccensis) and Por's goatfish (Upeneus pori). Most of these were studied by Güven et al. [93] along the Turkish coast, where in $29 \%-36 \%$ of the fish's stomach MP was found. Anastasopolou et al. [113] report a very MP intake by Chelon auratus in the Northern Adriatic Sea (Slovenian Sea) with $95 \%$ of the fish specimen studied having ingested MP, with a large number of MP found in the fish. Merluccius merluccius, the European hake, is commercially a very important fish that can be found in the East Atlantic, the Black Sea and the Mediterranean Sea. About 100,000 tonnes were landed by European fisheries in 2010, but the species is thought to be overfished. It is a predatory fish, predating also on pilchard and European anchovy. MP ingestion is relatively high for Merluccius merluccius [121] [122] [123], with the exception of data from two studies in the North Thyrrenian Sea [121] and the East Ionian Sea [113]. Looking at mackerels from the Carangidae family, early data, from 1998, showed little ingestion (1\% of the fish studied) in both Mediterranean horse mackerel (Trachurus mediterraneus) and blue jack mackerel (Trachurus picturatus), where the data may reflect the time period [124]. Later investigations showed much higher rates of ingestion, with $10 \%-48 \%$ of the fish from both the East Mediterranean along the Turkish coast [93] and the West Mediterranean Sea (Balearic Islands) [108] showing MP. Also, the Atlantic horse mackerel (Trachurus trachurus), caught in the South Adriatic Sea, showed appreciable (24\% of the fish) MP ingestion. The Mediterranean horse mackerel is commercially an important fish, both in the Mediterranean and the Black Sea, although regionally the catch has declined due to overfishing [125]. The Atlantic horse mackerel has been classified as a vulnerable species. Looking at the mackerels of the Scombridae family, data is known for the Atlantic chub mackerel (Scomber colias) and the Pacific mackerel (Scomber japonicus) as well as for two tuna fish, the albacore (Thunnus alalunga) and the bluefin tuna (Thunnus thynnus). The annual Thunnus alalunga catch in the Mediterranean is variable, but in 2010 it amounted to 2123 tonnes, with Italy being the main producer at 1109 tonnes [126]. In 2009, F.S. Karakulak et al. studied stomach contents of 218 bluefin tuna (from the Eastern Mediterranean Sea and had found plastic in 37 stomachs [127]. These plastics could be labelled as meso and macroplastics. At the time, the presence of MP was not documented. In 2015-2020, a number of studies were forwarded regarding MP ingestion in these fish, where the percentage of fish with MP was recorded at $12.9 \%$ for Thunnus alalunga [128], 32.3\% for Thunnus thynnus [128], 66.7\% for Scomber colias [123] and $43.2 \%$ - 57\% for Scomber japonicus [93]. In addition to $B$. boops, a number of seabream and porgy species were the subject of studies in the Adriatic Sea and the East Mediterranean Sea. Most studied is the common pandora (Pagellus erythrinus). The annual worldwide production of the common pandora decreased from about 10,000 tonnes (1981-1985) to 4500 tonnes [129]. The species is overexploited in several Mediterranean subareas. A study from the 
North Adriatic Sea and the NE Ionian Sea with altogether 80 specimen showed low MP ingestion (2\% - 3.3\%) [101]. Other studies, partially from the same area, but also from the East Mediterranean showed a higher percentage of fish with MP (22\% - 50\%) [93] [113] [114]. Other seabream species that were studied are the black seabream (Spondyliosoma cantharus), the white seabream (Diplodus sargus), the striped seabream (Lithognathus mormyrus), the axillary seabream (Pagellus acarne) the blackspot bream (Pagellus bogaraveo), the gilt-head bream (Sparus aurata) and the red porgy (Pagrus pagrus). All these species show heavy MP ingestion. Finally, MP ingestion of the common sole (Solea solea), a demersal species, a commercially important fish with catches worldwide amounting to 33,997 tonnes (FAO Fishfinder, species fact sheets, Solea solea) and with catches in the Adriatic Sea (Italy, Croatia, Slovenia) equaling 1645 tonnes in 2011 [130], has been studied a number of times in the Adriatic Sea. Results are varied, however, the largest study with 533 specimen, showed that $95 \%$ of the fish had MP in their gastrointestinal tract [131] (Figure 2).

Looking at the elasmobranch fish, sharks, many species of which are endangered [132], have been investigated extensively for MP content. In the Mediterranean Sea, elasmobranch fish catches make up only $1.15 \%$ of the total landings [133]. Additionally, the catches show a decreasing trend from 26,000 tons in 1983-1984 to 14,000 tons in 2015 [133]. Among the elasmobranch fish, the velvet belly lanternshark (Etmopterus spinax) has been one of the most studied in the Mediterranean Sea in regard to MP content [124] [134] [135] [136]. Although the species is of no commercial importance per se, it is often found in bycatch, especially in deepwater fishing operations. Here, MP findings are heterogeneous, where a number of studies have reported low MP ingestion rates for this shark species [135] [136]. Nevertheless, of 34 specimen of the velvet belly lanternshark from the Tyrrhenian Sea, 21 (61.8\%) were found with MP in their gastrointestinal tract. The blackmouth catshark (Galeus melastomus), a fish of limited commercial value within the Mediterranean region, is another species that has been thoroughly investigated for MP contamination [134] [135] [137] [138] [139]

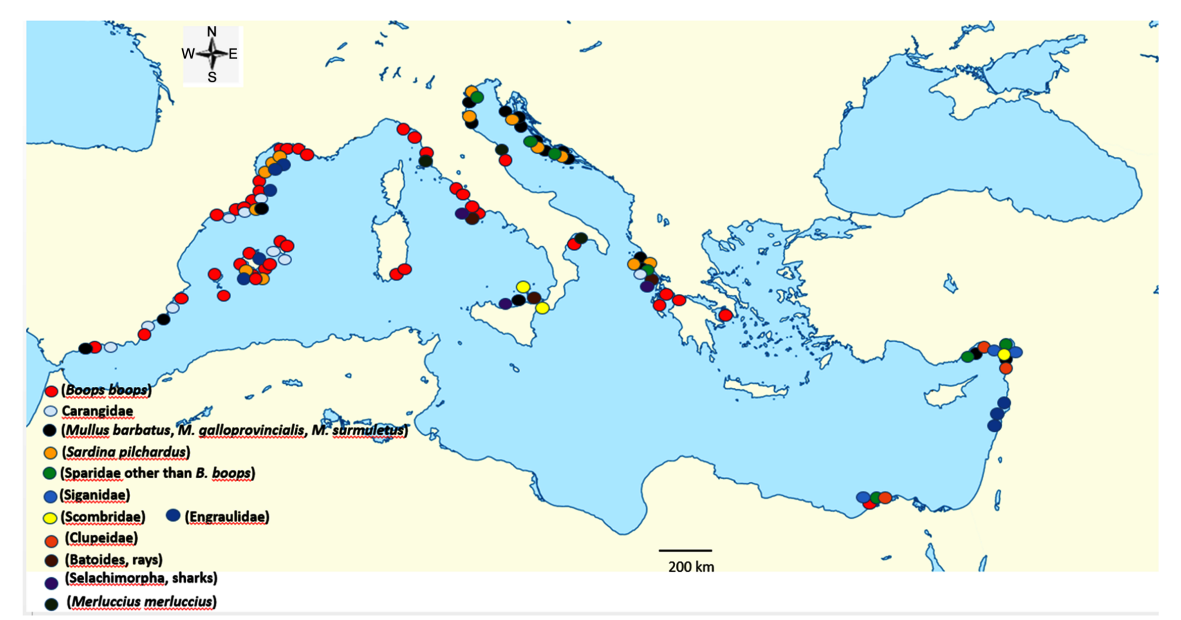

Figure 2. Sampling sites for different fish species for microplastic content screening. 
with large numbers of specimen per research study. Two reports [134] [135], from 2013 and 2016, noted that about 3.2\% of 866 specimen showed ingested MP. Later studies of the time period 2017-2020 [137] [139] reported higher ingestion rates in the blackmouth catshark from the Balearic Islands and from Thyrrenean Sea. Of more value for deepwater commercial fisheries is the Portuguese dogfish (Centroscymnus coelolepis), which is prized for its oil. For this species, two studies found little to no MP ingestion [135] [136]. The spiny dogfish (Squalus acanthias) is globally one of the more common shark species, however, in the Western Mediterranean it is quite rare. It is more common in the Eastern Mediterranean and also in the Black Sea, where it is fished commercially. Nevertheless, in the Mediterranean Sea the species is seen as endangered. A study of 2013 from the East Ionian Sea showed no MP ingestion in 10 spiny dogfish, a study of 2015 found MP in 4 out of the 9 spiny dogfish examined [122]. The small spotted catshark (Scyliorhynus canicula) is one of the most abundant sharks in the Mediterranean, but is of limited commercial value in the Mediterranean region. Two studies [138] [139], both from the Thyrrenian Sea, with 12 and 30 specimen, respectively, showed appreciable MP contamination in this species. Lastly, much less is known about MP ingestion of rays, where only a few specimen of the longnosed ray (Raja oxyrinchus, 10 specimen, 0\% MP) [134], the thornback ray (Raja clavata, 2 specimen, 0\% MP) [134] and the brown ray (Raja miraletus, one ray found with MP content) [138] have been analyzed for MP content.

\section{Conclusions}

Overall, the published data on MP content in fish of the Mediterranean Sea is quite heterogeneous. Keeping in mind that most of the data stems from 2013-2020 and that therefore the research area is still rather novel, having been previously focused on meso- and macroplastic ingestion, and that the research methodology has been refined over the years, early data [101] [134] often shows relatively little MP ingestion. Otherwise, there are areas within the Mediterranean where fish during the time of the study showed less MP ingestion. A typical example comes from the species B. boops where only $16.7 \%$ of the fish were found with MP in a study from the Balearic islands [108] and $13.0 \%$ in a study from South Sardinia [107]. Again, this data represents a "screenshot" of the species in that location at that particular time. Fish in neighboring locations within the same general region may give completely different data ([104], see above). There is an indication that deep sea catches show less MP content, though some of the data come from the early years of study (see above). Also, seasonal variations in currents and waste discharges can bring about significant differences in MP content along the water column as isolated events such as ship wrecks [140] or ships losing cargo en route. For litter in general, Vlachogianni et al. [101] [141] found the average number of litter per gut higher in fish from the South Adriatic Sea (2.2 P/gut) than from the northeastern Ionian and North Adriatic Sea (1.0 P/gut). 
What danger MP containing fish represent to humans is debatable, as with the gutting of fish most MP content is avoided. However, about $20 \%$ of fish landings go into fish meal which then is affected by the MP content in the fish. As fish meal also constitutes the offal of fish, the risk to utilize parts of the fish that hold MP is quite high [142]. E. encrasicolus, S. pilchardus, and T. trachurus are some of the main fish species that contribute to fish meal production, and studies have shown that these species carry MP content, when caught in the Mediterranean Sea.

To curb the increase in MP in the Mediterranean Sea, it is important to limit the entry of plastics in general by a better waste management at the community level, especially in the larger cities on the Mediterranean coast. Certain contributors to primary MP such as microbeads in cosmetics will be phased out in the near future and will no longer be of importance, others such as textile fibers and microtires will remain contributors to MP in general, although microtires specifically have not been recorded in fish to date. More important will be secondary MP resulting from the gradual breakdown of the overall solid plastic waste entering the Mediterranean Sea. Even without the introduction of additional plastic waste, secondary MP will remain with us for an indeterminable time in the future due to the long half-life of plastic materials, much of which will lastly degrade by passing through MP stages.

\section{Conflicts of Interest}

The authors declare no conflicts of interest regarding the publication of this paper.

\section{References}

[1] Verster, C. and Bouwman, H. (2020) Land-Based Sources and Pathways of Marine Plastics in a South African Context. South African Journal of Science, 116, Article No. 7700. https://doi.org/10.17159/sajs.2020/7700

[2] Habib, R.Z., Thiemann, T. and Al Kindi, R. (2020) Microplastics and Wastewater Treatment Plants. Journal of Water Resource and Protection, 12, 1-35. https://doi.org/10.4236/jwarp.2020.121001

[3] Ding, Y.C., Zou, X.Q., Wang, C.L., Feng, Z.Y., Wang, Y., Fan, Q.Y. and Chen, H.Y. (2021) The Abundance and Characteristics of Atmospheric Microplastic Deposition in the Northwestern South China Sea in the Fall. Atmospheric Environment, 253, Article ID: 118389. https://doi.org/10.1016/j.atmosenv.2021.118389

[4] Constant, M., Ludwig, W., Kerherve, P., Sola, J., Charriere, B., Sanchez-Vidal, A., Canals, M. and Heussner, S. (2020) Microplastic Fluxes in a Large and a Small Mediterranean River Catchments: The Tet and the Rhone, Northwestern Mediterranean Sea. Science of the Total Environment, 716, Article ID: 136984. https://doi.org/10.1016/j.scitotenv.2020.136984

[5] Ross, P.S., Chastain, S., Vassilenko, E., Eyemadifari, A., Zimmermann, S., Quesnel, S.-A., Eert, J., Solomon, E., Patankar, S., Posackar, A.M. and Williams, B. (2021) Pervasive Distribution of Polyester Fibres in the Arctic Ocean Is Driven by Atlantic Inputs. Nature Communications, 12, Article No. 106. https://doi.org/10.1038/s41467-020-20347-1 
[6] Kelly, A., Lannuzel, D., Rodemann, T., Meiners, K.M. and Auman, H.J. (2020) Microplastic Contamination in East Antarctic Sea Ice. Marine Pollution Bulletin, 154, Article ID: 111130. https://doi.org/10.1016/j.marpolbul.2020.111130

[7] GFCM (General Fisheries Commission for the Mediterranean) (2021) GFCM Capture Production (1970-2018). http://www.fao.org/gfcm/data/capture-production

[8] Food and Agriculture Organization of the United Nations (2017) Fishery and Aquaculture Statistics: RECOFI Capture Production 1986-2015. FishStatJ-Software for Fishery Statistical Time Series, Fisheries and Aquaculture Department, Food and Agriculture Organization of the United Nations, Rome. Updated 21 July 2016. http://www.fao.org/fishery/

[9] Vaughan, G.O., Al-Mansoori, N. and Burt, J.A. (2019) The Arabian Gulf. In: Sheppard, C., Ed., World Seas: An Environmental Evaluation, Vol. 2: The Indian Ocean to the Pacific, 2nd Edition, Academic Press, Cambridge, Chapter 1, 1-23. https://doi.org/10.1016/B978-0-08-100853-9.00001-4

[10] Sanders, M.J. and Morgan, G.R. (1989) Review of the Fisheries Resources of the Red Sea and Gulf of Aden. FAO Fisheries Technical Paper No. 304, Food and Agriculture Organization of the United Nations, Rome.

[11] Ministry of Environment Water \& Agriculture, The Kingdom of Saudi Arabia (2018) MEWA, Statistical Yearbook. Ministry of Environment Water \& Agriculture, The Kingdom of Saudi Arabia, Riyadh.

https://www.mewa.gov.sa/ar/InformationCenter/Researchs/Reports/Pages/default.a $\underline{\mathrm{spx}}$

[12] Tamele, I.J. and Loureiro, P.V. (2020) Lead, Mercury and Cadmium in Fish and Shellfish from the Indian Ocean and Red Sea (African Countries): Public Health Challenges. Journal of Marine Science and Engineering, 8, Article No. 344. https://doi.org/10.3390/jmse8050344

[13] Lenzi, M., Frianchi, E., Leporatti-Persiano, M., D’Agostino, A., Gennaro, P. and Marsili, L. (2021) Assessment of the Causes of Hg Bioaccumulation in the Fish of a Mediterranean Lagoon Subject to Environmental Management Interventions. Marine Pollution Bulletin, 162, Article ID: 111907. https://doi.org/10.1016/j.marpolbul.2020.111907

[14] Rochman, C.M., Tahir, A., Williams, S.L., Baxa, D.V., Lam, R., Miller, J.T., The, F.C., Werorilangi, S. and The, S.J. (2015) Anthropogenic Debris in Seafood: Plastic Debris and Fibers from Textiles in Fish and Bivalves Sold for Human Consumption. Scientific Reports, 5, Article No. 14340. https://doi.org/10.1038/srep14340

[15] Fang, C., Zheng, R.H., Chen, H.Z., Hong, F.K., Lin, L.S., Lin, H., Guo, H.G., Bailey, C., Segner, H., Mu, J.L. and Bo, J. (2019) Comparison of Microplastic Contamination in Fish and Bivalves from Two Major Cities in Fujian Province, China and the Implications for Human Health. Aquaculture, 512, Article ID: 734322. https://doi.org/10.1016/j.aquaculture.2019.734322

[16] Martellini, T., Guerranti, C., Scopetani, C., Ugolini, A., Chelazzi, D. and Cincinelli, A. (2018) A Snapshot of Microplastics in the Coastal Areas of the Mediterranean Sea. TrAC Trends in Analytical Chemistry, 109, 173-179. https://doi.org/10.1016/j.trac.2018.09.028

[17] Fytianos, G., Ioannidou, E., Thysiadou, A., Mitropoulos, A.C. and Kyzas, G.Z. (2021) Microplastics in Mediterranean Coastal Countries: A Recent Overview. Journal of Marine Science and Engineering, 9, Article No. 98. https://doi.org/10.3390/jmse9010098

[18] Sharma, S., Sharma, V. and Chatterjee, S. (2021) Microplastics in the Mediterranean 
Sea: Sources, Pollution Intensity, Sea Health, and Regulatory Policies. Frontiers in Marine Science, 8, Article No. 634934. https://doi.org/10.3389/fmars.2021.634934

[19] Deudero, S. and Alomar, C. (2015) Mediterranean Marine Biodiversity under Threat: Reviewing Influence of Marine Litter on Species. Marine Pollution Bulletin, 98, 58-68. https://doi.org/10.1016/j.marpolbul.2015.07.012

[20] Fossi, M.C., Peda, C., Compa, M., Tsangaris, C., Alomar, C., Claro, F., Ioakeimidis, C., Galgani, F., Hema, T., Deudero, S., Romeo, T., Battaglia, P., Andaloro, F., Caliani, I., Casini, S., Panti, C. and Baini, M. (2018) Bioindicators for Monitoring Marine Litter Ingestion and Its Impacts on Mediterranean Biodiversity. Environmental Pollution, 237, 1023-1040. https://doi.org/10.1016/j.envpol.2017.11.019

[21] Compa, M., Alomar, C., Wilcox, C., van Sebille, E., Lebreton, L., Hardesty, B.D. and Deudero, S. (2019) Risk Assessment of Plastic Pollution on Marine Diversity in the Mediterranean Sea. Science of the Total Environment, 678, 188-196.

https://doi.org/10.1016/j.scitotenv.2019.04.355

[22] Al-Salem, S.M., Uddin, S. and Al-Yamani, F. (2020) An Assessment of Microplastics Threat to the Marine Environment: A Short Review in Context of the Arabian/Persian Gulf. Marine Environmental Research, 159, Article ID: 104961. https://doi.org/10.1016/j.marenvres.2020.104961

[23] European Environment Agency (2015) Mediterranean Sea Region Briefing: The European Environment-State and Outlook 2015. https://www.eea.europa.eu/soer/2015/countries/mediterranean

[24] Erni-Cassola, G., Gibson, M.I., Thompson, R.C. and Christie-Oleza, J.A. (2017) Lost, but Found with Nile Red: A Novel Method for Detecting and Quantifying Small Microplastics ( $1 \mathrm{~mm}$ to $20 \mu \mathrm{m})$ in Environmental Samples. Environmental Science \& Technology, 51, 13641-13648. https://doi.org/10.1021/acs.est.7b04512

[25] de Haan, W. P., Sanchez-Vidal, A. and Canals, M. (2019) Floating Microplastics and Aggregate Formation in the Western Mediterranean Sea. Marine Pollution Bulletin, 140, 523-535. https://doi.org/10.1016/j.marpolbul.2019.01.053

[26] Thiemann, T. (2021) Isolation of Phthalates and Terephthalates from Plant Material-Natural Products or Contaminants? Open Chemistry Journal, 8, 1-36. http://dx.doi.org/10.2174/1874842202108010001

[27] Stadtmüller, S. (2002) Siloxanes as Additives for Plastics. Polymers \& Polymer Composites, 10, 49-61. https://doi.org/10.1177\%2F096739110201000104

[28] Capriotti, M., Cocci, P., Bracchetti, L., Cottone, E., Scandiffio, R., Caprioli, G., Sagratini, G., Mosconi, G., Bovolin, P. and Palermo, F.A. (2021) Microplastics and Their Associated Organic Pollutants from the Coastal Waters of the Central Adriatic Sea (Italy): Investigation of Adipogenic Effects in Vitro. Environmental Pollution, 263, Article ID: 128090. https://doi.org/10.1016/j.chemosphere.2020.128090

[29] Karkanorachaki, K., Kiparissis, S., Calypso, G., Kalogerakis, G.C., Yiantzi, E., Psillakis, E. and Kalogerakis, N. (2018) Plastic Pellets, Meso- and Microplastics on the Coastline of Northern Crete: Distribution and Organic Pollution. Marine Pollution Bulletin, 133, 578-589. https://doi.org/10.1016/j.marpolbul.2018.06.011

[30] Gugliandolo, E., Licata, P., Crupi, R., Albergamo, A., Jebara, A., Turco, V.L., Potorti, A.G., Mansour, H.B., Cuzzocrea, S. and di Bella, G. (2020) Plasticizers as Microplastics Tracers in Tunisian Marine Environment. Frontiers in Marine Science, 7, Article No. 589398. https://doi.org/10.3389/fmars.2020.589398

[31] Fossi, M.C., Coppola, D., Baini, M. Giannetti, M., Guerranti, C. Marsili, L., Panti, C., de Sabata, E. and Clò, S. (2014) Large Filter Feeder Marine Organisms as Indicators of Microplastic in the Pelagic Environment: The Case Studies of the Medi- 
terranean Basking Shark (Cetorhinus maximus) and Fin Whale (Balaenoptera physalus). Marine Environmental Research, 100, 17-24. https://doi.org/10.1016/j.marenvres.2014.02.002

[32] Schmidt, N., Castro-Jimenez, J., Oursel, B. and Sempéré, R. (2021) Phthalates and Organophosphate Esters in Surface Water, Sediments and Zooplankton of the NW Mediterranean Sea: Exploring Links with Microplastic Abundance and Accumulation in the Marine Food Web. Environmental Pollution, 272, Article ID: 115970. https://doi.org/10.1016/j.envpol.2020.115970

[33] Schantz, S.L., Moshtaghian J., Peterson, R.E. and Moore, R.W. (1996) Effects of Gestational and Lactational Exposure to TCDD or Coplanar PCBs on Spatial Learning. Neurotoxicology and Teratology, 18, 305-313.

https://doi.org/10.1016/S0892-0362(96)90033-1

[34] Butterworth, F.M., Pandey, R., McGowen, R.M., Ali-Sadat, S. and Walia, S. (1995) Genotoxicity of Polychlorinated Biphenyls (PCBs): Recombinogenesis by Biotransformation Products. Mutation Research, 342, 61-69. https://doi.org/10.1016/0165-1218(95)90090-X

[35] de Sá, L.C., Oliveira, M., Ribeiro, F. Rocha, T.L. and Futter, M.N. (2018) Studies of the Effects of Microplastics on Aquatic Organisms: What Do We Know and Where Should We Focus Our Efforts in the Future? Science of the Total Environment, 645, 1029-1039. https://doi.org/10.1016/j.scitotenv.2018.07.207

[36] Barboza, L.G.A., Vethaak, A.D., Lavorante, B.R.B.O., Lundebye, A.-K. and Guilherminoa, L. (2018) Marine Microplastic Debris: An Emerging Issue for Food Security, Food Safety and Human Health. Marine Pollution Bulletin, 133, 336-348. https://doi.org/10.1016/j.marpolbul.2018.05.047

[37] Prokić, M.D., Radovanović, T.B., Gavrić, J.P. and Faggio, C. (2019) Ecotoxicological Effects of Microplastics: Examination of Biomarkers, Current State and Future Perspectives. TrAC Trends in Analytical Chemistry, 111, 37-46. https://doi.org/10.1016/j.trac.2018.12.001

[38] Squadrone, S., Pederiva, S., Bezzo, T., Sartor, R.M., Battuello, M., Nurra, N., Griglione, A., Brizio, P. and Abete, M.C. (2021) Microplastics as Vectors of Metals Contamination in Mediterranean Sea. Environmental Science and Pollution Research. https://doi.org/10.1007/s11356-021-13662-7

[39] Mansui, J., Molcard, A. and Ourmières, Y. (2015) Modelling the Transport and Accumulation of Floating Marine Debris in the Mediterranean Basin. Marine Pollution Bulletin, 91, 249-257. https://doi.org/10.1016/j.marpolbul.2014.11.037

[40] Cózar, A., Sanz-Martín, M., Martí, E., González-Gordillo, J.I., Ubeda, B., Gálvez, J.Á., Irigoien, X. and Duarte, C.M. (2015) Plastic Accumulation in the Mediterranean Sea. PLoS ONE, 10, e0121762. https://doi.org/10.1371/journal.pone.0121762

[41] van Sibylle, E., Wilcox, C., Lebreton, L., Maximenko, N., Hardesty, B.D., van Franeker, J.A., Eriksen, M., Siegel, D., Galgani, F. and Law, K.L. (2015) A Global Inventory of Small Floating Plastic Debris. Environmental Research Letters, 10, Article ID: 124006. https://doi.org/10.1088/1748-9326/10/12/124006

[42] Morris, R.J. (1980) Floating Plastic Debris in the Mediterranean. Marine Pollution Bulletin, 11, 125. https://doi.org/10.1016/0025-326X(80)90073-9

[43] Kaandorp, M. L. A., Dijkstra, H. A. and van Sebille, E. (2020) Closing the Mediterranean Marine Floating Plastic Mass Budget: Inverse Modeling of Sources and Sinks. Environmental Science \& Technology, 54, 11980-11989. https://doi.org/10.1021/acs.est.0c01984

[44] de la Fuente, R., Drotos, G., Hernandez-Garcia, E., Lopez, C. and van Sebille, E. 
(2021) Sinking Microplastics in the Water Column: Simulations in the Mediterranean Sea. Ocean Science, 17, 431-453. https://doi.org/10.5194/os-17-431-2021

[45] Rummel, C.D., Jahnke, A., Gorokhova, E., Kühnel, D. and Schmitt-Jansen, M. (2017) Impacts of Biofilm Formation on the Fate and potential Effects of Microplastic in the Aquatic Environment. Environmental Science \& Technology Letters, 4, 258-267. https://doi.org/10.1021/acs.estlett.7b00164

[46] Godoy, V., Prata, J.C., Blázquez, G., Almendros, A.I., Duarte, A.C., Rocha-Santos, T., Calero, M. and Martín-Lara, M.A. (2020) Effects of Distance to the Sea and Geomorphological Characteristics on the Quantity and Distribution of Microplastics in Beach Sediments of Granada (Spain) Science of the Total Environment, 746, Article ID: 142023. https://doi.org/10.1016/j.scitotenv.2020.142023

[47] Lots, F.E.A., Behrens, P., Viyver, M.G., Horton, A.A. and Bosker, T. (2017) A Large-Scale Investigation of Microplastic Contamination: Abundance and Characteristics of Microplastics in European Beach Sediment. Marine Pollution Bulletin, 123, 219-226. https://doi.org/10.1016/j.marpolbul.2017.08.057

[48] Alomar, C., Estarellas, F. and Deudero, S. (2016) Microplastics in the Mediterranean Sea: Deposition in Coastal Shallow Sediments, Spatial Variation and Preferential Grain Size. Marine Environmental Research, 115, 1-10.

https://doi.org/10.1016/j.marenvres.2016.01.005

[49] Constant, M., Kerhervé, P., Mino-Vercellio-Verollet, M., Dumontier, M., Vidal, A. S., Canals, M. and Heussner, S. (2019) Beached Microplastics in the Northwestern Mediterranean Sea. Marine Pollution Bulletin, 142, 263-273. https://doi.org/10.1016/j.marpolbul.2019.03.032

[50] Merlino, S., Locritani, M., Bernardi, G., Como, C., Legnaioli, S., Palleschi, V. and Abbate, M. (2020) Spatial and Temporal Distribution of Chemically characterized Microplastics within the Protected Area of Pelagos Sanctuary (NW Mediterranean Sea): Focus on Natural and Urban Beaches. Water, 12, Article No. 3389. https://doi.org/10.3390/w12123389

[51] Cannas, S., Fastelli, P., Guerranti, C. and Renzi, M. (2017) Plastic Litter in Sediments from the Coasts of South Tuscany (Tyrrhenian Sea). Marine Pollution Bulletin, 119, 372-375. https://doi.org/10.1016/j.marpolbul.2017.04.008

[52] Guerranti, C., Cannas, S., Scopetani, C., Fastelli, P., Cincinelli, A. and Renzi, M. (2017) Plastic Litter in Aquatic Environments of Maremma Regional Park (Tyrrhenian Sea, Italy): Contribution by the Ombrone River and Levels in Marine Sediments. Marine Pollution Bulletin, 117, 366-370. https://doi.org/10.1016/j.marpolbul.2017.02.021

[53] Piazzolla, D., Cafaro, V., de Lucia, G.A., Mancini, E., Scanu, S., Bonamano, S., Piermattei, V., Vianello, A., Della Ventura, G. and Marcelli, M. (2020) Microlitter Pollution in Coastal Sediments of the Northern Tyrrhenian Sea, Italy: Microplastics and Fly-Ash Occurrence and Distribution. Estuarine Coastal and Shelf Science, 241, Article ID: 106819. https://doi.org/10.1016/j.ecss.2020.106819

[54] Romeo, T., D’Alessandro, M., Esposito, V., Scotti, G., Berto, D., Formalewicz, M., Noventa, S., Giuliani, S., Macchia, S., Sartori, D., Mazzola, A., Andaloro, F., Giacobbe, S., Deidun, A. and Renzi, M. (2015) Environmental Quality Assessment of Grand Harbour (Valletta, Maltese Islands): A Case Study of a Busy Harbour in the Central Mediterranean Sea. Environmental Monitoring and Assessment, 187, Aarticle No. 747. https://doi.org/10.1007/s10661-015-4950-3

[55] Vianello, A., Boldrin, A., Guerriero, P., Moschino, V., Rella, R., Sturaro, A. and Da Ros, L. (2013) Microplastic Particles in Sediments of Lagoon of Venice, Italy: First 
Observations on Occurrence, Spatial Patterns and Identification. Estuarine, Coastal and Shelf Science, 130, 54-61. https://doi.org/10.1016/j.ecss.2013.03.022

[56] Renzi, M., Blašković, A., Fastelli, P., Marcelli, M., Guerranti C., Cannas, S., Barone, L. and Massara, F. (2018) Is the Microplastic Selective According to the Habitat? Records in Amphioxus Sands, Mäerl Bed Habitats and Cymodocea nodosa Habitats. Marine Pollution Bulletin, 130, 179-183. https://doi.org/10.1016/j.marpolbul.2018.03.019

[57] Bajt, O., Szewc, K., Horvat, P., Pengal, P. and Grego, M. (2015) Microplastics in Sediments and Fish of the Gulf of Trieste. Proceedings of the MICRO 2015 Seminar on Microplastics Issues, Piran, 4-6 May 2015, 39-40.

[58] Laglbauer, B.J., Franco-Santos, R.M., Andreu-Cazenave, M., Brunelli, L., Papadatou, M., Palatinus, A., Grego, M. and Deprez, T. (2014) Macrodebris and Microplastics from Beaches in Slovenia. Marine Pollution Bulletin, 89, 356-366. https://doi.org/10.1016/j.marpolbul.2014.09.036

[59] Korez, S., Gutow, L. and Saborowski, R. (2019) Microplastics at the Strandlines of Slovenian Beaches. Marine Pollution Bulletin, 145, 334-342. https://doi.org/10.1016/j.marpolbul.2019.05.054

[60] Kazour, M., Jema, S., Issa, C., Khalaf, G. and Amara, R. (2019) Microplastics Pollution along the Lebanese Coast (Eastern Mediterranean Basin): Occurrence in Surface Water, Sediments and Biota Samples. Science of the Total Environment, 696, Article ID: 133933. https://doi.org/10.1016/j.scitotenv.2019.133933

[61] Shabaka, S.H., Ghobashy, M. and Marey, R.S. (2019) Identification of Marine Microplastics in Eastern Harbor, Mediterranean Coast of Egypt, Using Differential Scanning Calorimetry. Marine Pollution Bulletin, 142, 494-503.

https://doi.org/10.1016/j.marpolbul.2019.03.062

[62] Missawi, O., Bousserrhine, N. Belbekhouche, S., Zitounia, N., Alphonse, V., Boughattas, I. and Bannia, M. (2020) Abundance and Distribution of Small Microplastics $(\leq 3 \mu \mathrm{m})$ in Sediments and Seaworms from the Southern Mediterranean Coasts and Characterisation of Their Potential Harmful Effects. Environmental Pollution, 263, Article ID: 114634. https://doi.org/10.1016/j.envpol.2020.114634

[63] Chouchene, K., da Costa, J.P., Wali, A., Girao, A.V., Hentati, O., Duarte, A.C., Rocha-Santos, T. and Ksibi, M. (2019) Microplastic Pollution in the Sediments of Sidi Mansour Harbor in Southeast Tunisia. Marine Pollution Bulletin, 146, 92-99. https://doi.org/10.1016/j.marpolbul.2019.06.004

[64] Abidli, S., Antunes, J.C., Ferreira, J.L., Lahbib, Y., Sobral, P. and Trigui El Menif, N. (2018) Microplastics in Sediments from the Littoral Zone of the North Tunisian Coast (Mediterranean Sea). Estuarine, Coastal and Shelf Science, 205, 1-9. https://doi.org/10.1016/j.ecss.2018.03.006

[65] Abidli, S., Toumi, H., Lahbib, Y. and Trigui El Menif, N. (2017) The First Evaluation of Microplastics in Sediments from the Complex Lagoon-Channel of Bizerte (Northern Tunisia). Water, Air, \& Soil Pollution, 228, Article No. 262.

https://doi.org/10.1007/s11270-017-3439-9

[66] Tata, T., Belabed, B. E., Bououdina, M. and Bellucci, S. (2020) Occurrence and Characterization of Surface Sediment Microplastics and Litter from North African Coasts of Mediterranean Sea: Preliminary Research and First Evidence. Science of the Total Environment, 713, Article ID: 136664. https://doi.org/10.1016/j.scitotenv.2020.136664

[67] Taïbi, N.-E., Bentaallah, M.E.A., Alomar, C., Compa, M. and Deudero, S. (2021) Micro- and Macro-Plastics in Beach Sediment of the Algerian Western Coast: First 
Data on Distribution, Characterization, and Source. Marine Pollution Bulletin, 165, Article ID: 112168. https://doi.org/10.1016/j.marpolbul.2021.112168

[68] van der Hal, N., Ariel, A. and Angel, D.L. (2017) Exceptionally High Abundances of Microplastics in the Oligotrophic Israeli Mediterranean Coastal Waters. Marine Pollution Bulletin, 116, 151-155. https://doi.org/10.1016/j.marpolbul.2016.12.052

[69] Filgueiras, A.V., Gago, J., Campillo, J.A. and Leòn, V.M. (2019) Microplastic Distribution in Surface Sediments along the Spanish Mediterranean Continental shelf. Environmental Science and Pollution Research, 26, 21264-21273. https://doi.org/10.1007/s11356-019-05341-5

[70] Mistri, M., Scoponi, M., Granat, T., Moruzzi, L., Massara, F. and Munari, C. (2020) Types, Occurrence and Distribution of Microplastics in Sediments from the Northern Tyrrhenian Sea. Marine Pollution Bulletin, 153, Article ID: 111016. https://doi.org/10.1016/j.marpolbul.2020.111016

[71] Mistri, M., Infantini, V., Scoponi, M., Granata, T., Moruzzi, L., Massara, F., De Donati, M. and Munari, C. (2017) Small Plastic Debris in Sediments from the Central Adriatic Sea: Types, Occurrence and Distribution. Marine Pollution Bulletin, 124, 435-440. https://doi.org/10.1016/j.marpolbul.2017.07.063

[72] Fastelli, P., Blašković, A., Bernardi, G., Romeo, T., Čižmek, H., Andaloro, F., Russo, G. F., Guerranti, C. and Renzi, M. (2016) Plastic Litter in Sediments from a Marine Area Likely to Become Protected (Aeolian Archipelago's Islands, Tyrrhenian Sea) Marine Pollution Bulletin, 113, 526-529. https://doi.org/10.1016/j.marpolbul.2016.08.054

[73] Palatinus, A., Viršeka, M., Robič, U., Grego, M. Bajt, O., Šiljić, J., Suaria, G., Liubartseva, S., Coppini, G. and Peterlin, M. (2019) Marine Litter in the Croatian Part of the Middle Adriatic Sea: Simultaneous Assessment of Floating and Seabed Macro and Micro Litter Abundance and Composition. Marine Pollution Bulletin, 139, 427-439. https://doi.org/10.1016/j.marpolbul.2018.12.038

[74] Blašković, A. Fastell, P., Čižmek, H., Guerranti, C. and Renzi, M. (2017) Plastic Litter in Sediments from the Croatian Marine Protected Area of the Natural Park of Telaščica Bay (Adriatic Sea). Marine Pollution Bulletin, 114, 583-586. https://doi.org/10.1016/j.marpolbul.2016.09.018

[75] Van Cauwenberghe, L., Vanreuse, A., Mees, J. and Janssen, C.R. (2013) Microplastic Pollution in Deep-Sea Sediments. Environmental Pollution, 182, 495-499. https://doi.org/10.1016/j.envpol.2013.08.013

[76] Faure, F., Saini, C., Potter, G., Galgani, F., de Alencastro, L.F. and Hagmann, P. (2015) An Evaluation of Surface Micro- and Mesoplastic Pollution in Pelagic Ecosystems of the Western Mediterranean Sea. Environmental Science and Pollution Research, 22, 12190-12197. https://doi.org/10.1007/s11356-015-4453-3

[77] Ruiz-Orejón, L.F., Sardá, R. and Ramis-Pujol, J. (2018) Now, You See Me: High Concentrations of Floating Plastic Debris in the Coastal Waters of the Balearic Islands (Spain) Marine Pollution Bulletin, 133, 636-646.

https://doi.org/10.1016/j.marpolbul.2018.06.010

[78] Schmidt, N., Thibault, D., Galgani, F., Paluselli, A. and Sempéré, R. (2018) Occurrence of Microplastics in Surface Waters of the Gulf of Lion (NW Mediterranean Sea). Progress in Oceanography, 163, 214-220.

https://doi.org/10.1016/j.pocean.2017.11.010

[79] Collignon, A., Hecq, J.-H., Glagani, F., Voisin, P., Collard, F. and Goffart, A. (2012) Neustonic Microplastic and Zooplankton in the North Western Mediterranean Sea. Marine Pollution Bulletin, 64, 861-864. 
https://doi.org/10.1016/j.marpolbul.2012.01.011

[80] Onrubia, J. A. T., Djaoudi, K., Borgogno, F., Canuto, S., Angeletti, B., Besio, G., Capello, M., Cutroneo, L., Stocchino, A., Mounier, S. and Lenoble, V. (2021) Quantification of Microplastics in North-Western Mediterranean Harbors: Seasonality and Biofilm-Related Metallic Contaminants. Journal of Marine Science and Engineering, 9, Article No. 337. https://doi.org/10.3390/jmse9030337

[81] Pedrotti, M. L., Petit, S., Elineau, A., Bruzaud, S., Crebassa, J.-C., Dumontet, B., Martí, E., Gorsky, G. and Cózar, A. (2016) Changes in the Floating Plastic Pollution of the Mediterranean Sea in Relation to the Distance to Land. PLoS ONE, 11, e0161581. https://doi.org/10.1371/journal.pone.0161581

[82] Caldwell, J., Petri-Finka, A., Rothen-Rutishauser, B. and Lehner, R. (2019) Assessing Meso- and Microplastic Pollution in the Ligurian and Tyrrhenian Seas. Marine Pollution Bulletin, 149, Article ID: 110572. https://doi.org/10.1016/j.marpolbul.2019.110572

[83] Caldwell, J., Muff, L.F., Pham, C.K., Petri-Fink, A., Rothen-Rutishauser, B. and Lehner, R. (2020) Spatial and Temporal Analysis of Meso- and Microplastic Pollution in the Ligurian and Tyrrhenian Seas. Marine Pollution Bulletin, 159, Article ID: 111515. https://doi.org/10.1016/j.marpolbul.2020.111515

[84] Baini, M., Fossi, M.C., Galli, M., Caliani, J., Campani, T., Finoia, M.G. and Panti, C. (2018) Abundance and Characterization of Microplastics in the Coastal Waters of Tuscany (Italy): The Application of the MSFD Monitoring Protocol in the Mediterranean Sea. Marine Pollution Bulletin, 133, 543-552. https://doi.org/10.1016/j.marpolbul.2018.06.016

[85] Collignon, A., Hecq, J.-H., Galgani, F., Collard, F. and Goffart, A. (2014) Annual variation in Neustonic Micro- and Meso-Plastic Particles and Zooplankton in the Bay of Calvi (Mediterranean-Corsica). Marine Pollution Bulletin, 79, 293-298. https://doi.org/10.1016/j.marpolbul.2013.11.023

[86] Panti, C., Giannetti, M., Baini, M., Rubegni, F., Minutoli, R. and Fossi, M.C. (2015) Occurrence, Relative Abundance and Spatial Distribution of Microplastics and Zooplankton NW of Sardinia in the Pelagos Sanctuary Protected Area, Mediterranean Sea. Environmental Chemistry, 12, 618-625. https://doi.org/10.1071/EN14234

[87] de Lucia, G.A., Caliani, I., Marra, S., Camedda, A., Coppa, S., Alcaro, L., Campani, T., Giannetti, M., Coppola, D., Cicero, A.M., Panti, C., Baini, M., Guerranti, C., Marsili, L., Massaro, G., Fossi, M.C. and Matiddi, M. (2014) Amount and Distribution of Neustonic Micro-Plastic off the Western Sardinian Coast (Central-Western Mediterranean Sea) Marine Environmental Research, 100, 10-16.

https://doi.org/10.1016/j.marenvres.2014.03.017

[88] Gajšt, T., Bizjak, T., Palatinus, A., Liubartseva, S. and Kržan, A. (2016) Sea Surface Microplastics in Slovenian Part of the Northern Adriatic. Marine Pollution Bulletin, 113, 392-399. https://doi.org/10.1016/j.marpolbul.2016.10.031

[89] Zeri, C., Adamopoulou, A., Bojanić Varezić, D., Fortibuoni, T., Kovač Viršek, M., Kržan, A., Mandic, M., Mazziotti, C., Palatinus, A., Peterline M., Prvani, M., Ronchi, F., Siljic, J., Tutman, P. and Vlachogianni, T. (2018) Floating Plastics in Adriatic Waters (Mediterranean Sea): From the Macro- to the Micro-Scale. Marine Pollution Bulletin, 136, 341-350. https://doi.org/10.1016/j.marpolbul.2018.09.016

[90] Kornilios, S., Drakopoulos, P. and Dounas, C. (1998) Pelagic Tar, Dissolved/Dispersed Petroleum Hydrocarbons and Plastic Distribution in the Cretan Sea, Greece. Marine Pollution Bulletin, 36, 989-993.

https://doi.org/10.1016/S0025-326X(98)00102-7 
[91] Gündoğdu, S. and Çevik, C. (2017) Micro- and Mesoplastics in Northeast Levantine Coast of Turkey: The Preliminary Results from Surface Samples. Marine Pollution Bulletin, 118, 341-347. https://doi.org/10.1016/j.marpolbul.2017.03.002

[92] Gündoğdu, S. (2017) High Level of Micro-Plastic Pollution in the Iskenderun Bay NE Levantine Coast of Turkey. Ege Journal of Fisheries and Aquatic Sciences, 34, 401-408. https://doi.org/10.12714/egejfas.2017.34.4.06

[93] Güven, O., Gökdağ, K., Jovanović, B. and Kıdeyş, A.E. (2017) Microplastic Litter composition of the Turkish Territorial Waters of the Mediterranean Sea, and Its Occurrence in the Gastrointestinal Tract of Fish. Environmental Pollution, 223, 286-294. https://doi.org/10.1016/j.envpol.2017.01.025

[94] Wakkaf, T., El Zrelli, R., Kedzierski, M., Balti, R., Shaiek, M., Mansour, L., Tlig-Zouari, S., Bruzaud, S. and Rabaoui, L. (2020) Characterization of Microplastics in the Surface Waters of an Urban Lagoon (Bizerte lagoon, Southern Mediterranean Sea): Composition, Density, Distribution, and Influence of Environmental factors. Marine Pollution Bulletin, 160, Article ID: 111625. https://doi.org/10.1016/j.marpolbul.2020.111625

[95] Setiti, S., Hamdi, B., Chernai, S., Bachari, F.H., Bachouche, S., Ghezali, Y. and Suaria, G. (2021) Seasonal Variation of Microplastics Density in Algerian Surface Waters (South-Western Mediterranean Sea) Mediterranean Marine Science, 22, 317-326. https://doi.org/10.12681/mms.24899

[96] Simon-Sánchez, L., Grelaud, M., Garcia-Orellana, J. and Ziveri, P. (2019) River Deltas as Hotspots of Microplastic Accumulation: The Case Study of the Ebro River (NW Mediterranean). Science of the Total Environment, 687, 1186-1196. https://doi.org/10.1016/j.scitotenv.2019.06.168

[97] Pasquini, G., Ronchi, F., Strafella, P., Scarcella, G. and Fortibuoni, T. (2016) Seabed Litter Composition, Distribution and Sources in the Northern and Central Adriatic Sea (Mediterranean). Waste Management, 58, 41-51. https://doi.org/10.1016/j.wasman.2016.08.038

[98] Galgani, F., Leaute, J.P., Moguedet, P., Souplet, A., Verin, Y., Carpentier, A., Goraguere, H., Latrouite, D., Andral, B., Cadiou, Y., Mahe, J.C., Poulard, J.C. and Nerisson, P. (2000) Litter on the Sea Floor along European Coasts. Marine Pollution Bulletin, 40, 516-527. https://doi.org/10.1016/S0025-326X(99)00234-9

[99] Liubartseva, S., Coppini, G., Lecci, R. and Clementi, E. (2018) Tracking Plastics in the Mediterranean: 2D Lagrangian Model. Marine Pollution Bulletin, 129, 151-162. https://doi.org/10.1016/j.marpolbul.2018.02.019

[100] Burgan, H.I. and Aksoy, H. (2018) Annual Flow Duration Curve Model for Ungauged Basins. Hydrology Research, 49, 1684-1695.

https://doi.org/10.2166/nh.2018.109

[101] Vlachogianni, T., Anastasopoulou, A., Fortibuoni, T., Ronchi, F. and Zeri, C. (2017) Marine Litter Assessment in the Adriatic \& Ionian Seas. DeFishGear. https://mio-ecsde.org/wp-content/uploads/2017/02/Final-MLA-pages_final.pdf

[102] Kane, I.A., Clare, M.A., Miramontes, E., Wogelius, R., Rothwell, J.J., Garreau, P. and Pohl, F. (2020) Seafloor Microplastic Hotspots Controlled by Deep-Sea Circulation. Science, 368, 1140-1145. 9 https://doi.org/10.1126/science.aba5899

[103] Tubau, X., Canals, M., Lastras, G., Rayo, X., Rivera, J. and Amblas, D. (2015) Marine Litter on the Floor of Deep Submarine Canyons of the Northwestern Mediterranean Sea: The Role of Hydrodynamic Processes. Progress in Oceanography, 134, 379-403. https://doi.org/10.1016/j.pocean.2015.03.013

[104] Garcia-Garin, O., Vighi, M., Aguilar, A., Tsangaris, C., Digka, N., Kaberi, H. and 
Borrell, A. (2019) Boops boops as a Bioindicator of Microplastic Pollution along the Spanish Catalan Coast. Marine Pollution Bulletin, 149, Article ID: 110648. https://doi.org/10.1016/j.marpolbul.2019.110648

[105] Nadal, M.A., Alomar, C. and Deudero, S. (2016) High Levels of Microplastic Ingestion by the Semipelagic Fish Bogue Boops boops (L.) around the Balearic Islands. Environmental Pollution, 214, 517-523. https://doi.org/10.1016/j.envpol.2016.04.054

[106] Sbrana, A., Valente, T., Scacco, U., Bianchi, J., Silvestri, C., Palazzo, L., de Lucia, G.A., Valerani, C., Ardizzone, G. and Matidd, M. (2020) Spatial Variability and Influence of Biological Parameters on Microplastic Ingestion by Boops boops (L.) along the Italian Coasts (Western Mediterranean Sea) Environmental Pollution, 263, Article ID: 114429. https://doi.org/10.1016/j.envpol.2020.114429

[107] Tsangaris, C., Digka, N., Valente,T., Aguilar, A. Borrell, A., de Lucia, G.A., Gambaiani, D., Garcia-Garin, O., Kaberi, H., Martin, J., Mauriño, E., Miaud, C., Palazzo, L., del Olmo, A.P., Raga, J.A., Sbrana, A., Silvestri, C., Skylaki, E., Vighi, M., Wongdontree, P. and Matiddi, M. (2020) Using Boops boops (Osteichthyes) to Assess Microplastic Ingestion in the Mediterranean Sea. Marine Pollution Bulletin, 158, Article ID: 111397. https://doi.org/10.1016/j.marpolbul.2020.111397

[108] Rios-Fuster, B., Alomar, C., Compa, M., Guijarro, B. and Deudero, S. (2019) Anthropogenic Particles Ingestion in Fish Species from Two Areas of the Western Mediterranean Sea. Marine Pollution Bulletin, 144, 325-333.

https://doi.org/10.1016/j.marpolbul.2019.04.064

[109] Food and Agriculture Organization of the United Nations (2017) Fisheries Global Information System-Boops boops. http://www.fao.org/fishery/species/2385/en

[110] Dahel, A., Rachedi, M., Tahri, M., Benchikh, N., Diaf, A. and Djebar, A.B. (2019) Fisheries Status of the Bogue Boops boops (Linnaeus, 1758) in Algerian East Coast (Western Mediterranean Sea). Egyptian Journal of Aquatic Biology \& Fisheries, 23, 577-589. https://doi.org/10.21608/ejabf.2019.60554

[111] Compa, M., Ventero, A., Iglesias, M. and Deudero, S. (2018) Ingestion of Microplastics and Natural Fibres in Sardina pilchardus (Walbaum, 1792) and Engraulis encrasicolus (Linnaeus, 1758) along the Spanish Mediterranean Coast. Marine Pollution Bulletin, 128, 89-96. https://doi.org/10.1016/j.marpolbul.2018.01.009

[112] Lefebrve, C., Saraux, C., Heitz, O., Nowaczyk, A. and Bonnet, D. (2019) Microplastics FTIR Characterisation and Distribution in the Water Column and Digestive Tracts of Small Pelagic Fish in the Gulf of Lions. Marine Pollution Bulletin, 142, 510-519. https://doi.org/10.1016/j.marpolbul.2019.03.025

[113] Anastasopoulou, A., Viršek, M. K., Varezić, D.B., Digka, N., Fortibuoni, T., Koren, S., Mandić, M., Mytilineou, C., Pešić, A., Ronchi, F., Šiljić, J., Torre, M., Tsangaris, C. and Tutman, P. (2018) Assessment on Marine Litter Ingested by Fish in the Adriatic and NE Ionian Sea Macro-Region (Mediterranean). Marine Pollution Bulletin, 133, 841-851. https://doi.org/10.1016/j.marpolbul.2018.06.050

[114] Digka, N., Tsangaris, C., Torre, M., Anastasopoulou, A. and Zeri, C. (2018) Microplastics in Mussels and Fish from the Northern Ionian Sea. Marine Pollution Bulletin, 135, 30-40. https://doi.org/10.1016/j.marpolbul.2018.06.063

[115] Renzi, M., Specchiulli, A., Blašković, A., Manzo, C., Mancinelli, G. and Cilenti, L. (2019) Marine Litter in Stomach Content of Small Pelagic Fishes from the Adriatic Sea: Sardines (Sardina pilchardus) and Anchovies (Engraulis encrasicolus) Environmental Science and Pollution Research, 26, 2771-2781.

https://doi.org/10.1007/s11356-018-3762-8 
[116] Adika, S., Adika, A., Mahu, E., Crane, R., Marchant, R., Montford, J., Folorunsho, R. and Gordon, C. (2020) Microplastic Ingestion by Pelagic and Demersal Fish Species from the Eastern Central Atlantic Ocean, off the Coast of Ghana. Marine Pollution Bulletin, 153, Article ID: 110998. https://doi.org/10.1016/j.marpolbul.2020.110998

[117] Shabaka, S.H., Marey, R.S., Ghobashy, M., Abushady, A.M., Ismail, G.A. and Khairy, H.M. (2020) Thermal Analysis and Enhanced Visual Technique for Assessment of Microplastics in Fish from an Urban Harbor, Mediterranean Coast of Egypt. Marine Pollution Bulletin, 159, Article ID: 111465.

https://doi.org/10.1016/j.marpolbul.2020.111465

[118] Collard, F., Gilbert, B., Eppe, G., Parmentier, E. and Das, K. (2015) Detection of Anthropogenic Particles in Fish Stomachs: An Isolation Method Adapted to Identification by Raman Spectroscopy. Archives of Environmental Contamination and Toxicology, 69, 331-339. https://doi.org/10.1007/s00244-015-0221-0

[119] Milisenda, G. (2015) Stock Assessment Form of MUT (M. barbatus) in Combined GSA 15-16.

https://gfcmsitestorage.blob.core.windows.net/documents/SAC/SAF/DemersalSpeci es/2016/MUT_GSA_15-16_2015_MLT_ITA.pdf

[120] Alomar, C., Sureda, A., Capó, X., Guijarro, B., Tejada, S. and Deudero, S. (2017) Microplastic Ingestion by Mullus surmuletus Linnaeus, 1758 Fish and Its Potential for Causing Oxidative Stress. Environmental Research, 159, 135-142. https://doi.org/10.1016/j.envres.2017.07.043

[121] Giani, D., Baimni, M., Galli, M., Casini, S. and Fossi, M.C. (2019) Microplastics Occurrence in Edible Fish Species (Mullus barbatus and Merluccius merluccius) Collected in Three Different Geographical Sub-Areas of the Mediterranean Sea. Marine Pollution Bulletin, 140, 129-137. https://doi.org/10.1016/j.marpolbul.2019.01.005

[122] Avio, C.G., Gorbi, S. and Regoli, F. (2015) Experimental Development of a New Protocol for Extraction and Characterization of Microplastics in Fish Tissues: First Observations in Commercial Species from Adriatic Sea. Marine Environmental Research, 111, 18-26. https://doi.org/10.1016/j.marenvres.2015.06.014

[123] Bianchi, J., Valente, T., Scacco, U., Cimmaruta, R., Sbrana, A., Silvestri, C. and Matiddi, M. (2020) Food Preference Determines the Best Suitable Digestion Protocol for Analysing Microplastic Ingestion by Fish. Marine Pollution Bulletin, 154, Article ID: 111050. https://doi.org/10.1016/j.marpolbul.2020.111050

[124] Deudero, S. (1998) Relaciones troficas en las comunidades ícticas asociadas a dispositivos agregadores de peces. $\mathrm{PhD}$ Thesis, University of the Balearic Islands, Palma.

[125] Turan, C. (2004) Stock Identification of Mediterranean Horse Mackerel (Trachurus mediterraneus) Using Morphometric and Meristic Characters. ICES Journal of Marine Science, 61, 774-781. https://doi.org/10.1016/j.icesjms.2004.05.001

[126] ICCAT Standing Committee on Research and Statistics (ICCAT-SCRS) (2011) Stock Status Report 2011. Albacore-Mediterranean Sea. FIRMS Reports. In: Fisheries and Resources Monitoring System (FIRMS). Food and Agriculture Organization of the United Nations, Rome. http://firms.fao.org/firms/resource/6/en

[127] Karakulak, F.S., Salman, A. and Oray, I.K. (2009) Diet Composition of Bluefin Tuna (Thunnus thynnus L. 1758) in the Eastern Mediterranean Sea, Turkey. Journal of Applied Ichthyology, 25, 757-761. https://doi.org/10.1111/j.1439-0426.2009.01298.x

[128] Romeo, T., Pietro, B., Pedà, C., Consoli, P., Andaloro, F. and Fossi, M.C. (2015) 
First Evidence of Presence of Plastic Debris in Stomach of Large Pelagic Fish in the Mediterranean Sea. Marine Pollution Bulletin, 95, 358-361.

https://doi.org/10.1016/j.marpolbul.2015.04.048

[129] Coelho, R., Luis Bentes, L., Correia, C., Gonçalves, J. M. S., Lino, P. G., Monteiro, P., Ribeiro, J. and Erzini, K. (2010) Life History of the Common Pandora, Pagellus erythrinus (Linnaeus, 1758) (Actinopterygii: Sparidae) from Southern Portugal. Brazilian Journal of Oceanography, 58, 233-245. https://doi.org/10.1590/S1679-87592010000300006

[130] Milisenda, G. (2012) Stock Assessment Form Demersal Species-Stock Assessment of Common Sole in GSA17.

https://gfcmsitestorage.blob.core.windows.net/documents/SAC/SAFs/DemersalSpec ies/2011/SOLE_GSA17_FINAL.pdf

[131] Pellini, G., Gomiero, A., Fortibuoni, T., Ferrà, C., Grati, F., Tassetti, A.N., Polidori, P., Fabi, G. and Scarcella, G. (2018) Characterization of Microplastic Litter in the Gastrointestinal Tract of Solea solea from the Adriatic Sea. Environmental Pollution, 234, 943-952. https://doi.org/10.1016/j.envpol.2017.12.038

[132] Cashion, M.A., Bailly, N. and Pauly, D. (2019) Official Catch Data Underrepresent Shark and Ray Taxa Caught in Mediterranean and Black Sea fisheries. Marine Policy, 105, 1-9. https://doi.org/10.1016/j.marpol.2019.02.041

[133] Bradai, M.N., Saidi, B. and Enajjar, S. (2018) Overview on Mediterranean Shark's Fisheries: Impact on the Biodiversity. In: Türkoğlu, M., Önal, U. and Ismen, A., Eds., Marine Ecology-Biotic and Abiotic Interactions, IntechOpen, London. https://doi.org/10.5772/intechopen.74923

[134] Anastasopoulou, A., Mytilineou, C., Smith, C.J. and Papadopoulou, K.N. (2013) Plastic Debris Ingested by Deep-Water Fish of the Ionian Sea (Eastern Mediterranean). Deep-Sea Research I, 74, 11-13. https://doi.org/10.1016/j.dsr.2012.12.008

[135] Cartes, J. E., Soler-Membrives, A., Stefanescu, C., Lombarte, A. and Carrassón, M. (2016) Contributions of Allochthonous Inputs of Food to the Diets of Benthopelagic Fish over the Northwest Mediterranean Slope (to 2300m) Deep Sea Research Part I, Oceanographic Research Papers, 109, 123-136. https://doi.org/10.1016/j.dsr.2015.11.001

[136] Carrasón, M., Stefanescu, C. and Cartes, J.E. (1992) Diets and Bathymetric Distributions of Two Bathyal Sharks of the Catalan Deep Sea (Western Mediterranean) Marine Ecology Progress Series, 82, 21-30. https://doi.org/10.3354/meps082021 http://www.int-res.com/articles/meps/82/m082p021.pdf

[137] Alomar, C. and Deudero, S. (2017) Evidence of Microplastic Ingestion in the Shark Galeus melastomus Rafinesque, 1810 in the Continental Shelf Off the Western Mediterranean Sea. Environmental Pollution, 223, 223-229. https://doi.org/10.1016/j.envpol.2017.01.015

[138] Capillo, G., Savoca, S., Panarello, G., Mancuso, M., Branca, C., Romano, V., D’Angelo, G., Bottari, T. and Spanò, N. (2020) Quali-Quantitative Analysis of Plastics and Synthetic Microfibers Found in Demersal Species from Southern Tyrrhenian Sea (Central Mediterranean). Marine Pollution Bulletin, 150, Article ID: 110596. https://doi.org/10.1016/j.marpolbul.2019.110596

[139] Valente, T., Sbrana, A., Scacco, U., Jacomini, C. Bianchi, J., Palazzo, L., de Lucia, G.A., Silvestri, C. and Matiddi, M. (2019) Exploring Microplastic Ingestion by Three Deep-Water Elasmobranch Species: A Case Study from the Tyrrhenian Sea. Environmental Pollution, 253, 342-350.

https://doi.org/10.1016/j.envpol.2019.07.001 
[140] Avio, C. G., Cardelli, L. R., Gorbi, S., Pellegrini, D. and Regoli, F. (2017) Microplastics Pollution after the Removal of the Costa Concordia Wreck: First Evidences from a Biomonitoring Case Study. Environmental Pollution, 227, 207-214. https://doi.org/10.1016/j.envpol.2017.04.066

[141] Vlachogianni, T., Fortibuoni, T., Ronchi, F., Zeric, C., Mazziotti, C., Tutman, P., Bojanić Varezić, D. Palatinus, A., Trdan, S., Peterlin, M., Mandić, M., Markovic, O., Prvan, M., Kaberi, H., Prevenios, M., Kolitari, J., Kroqi, G., Fusco, M., Kalampokis, E. and Scoullos, M. (2018) Marine Litter on the Beaches of the Adriatic and Ionian Seas: An Assessment of Their Abundance, Composition and Sources. Marine Pollution Bulletin, 131, 745-756. https://doi.org/10.1016/j.marpolbul.2018.05.006

[142] Thiele, C., Hudson, M.D., Russell, A.E., Saluveer, M. and Sidaoui-Haddad, G. (2021) Microplastics in Fish and Fishmeal: An Emerging Environmental Challenge? Scientific Reports, 11, Article No. 2045. https://doi.org/10.1038/s41598-021-81499-8 